\title{
Pendekatan Living Values Education Dalam Pembelajaran Pai Dan Budi Pekerti Sebagai Upaya Membentuk Islamic Value Morality Peserta Didik
}

\author{
Rofi'ah Nurhayati \\ SMK Trisula 1 Depok Sleman \\ Email: rofiah.nurhayati@yahoo.co.id
}

\begin{abstract}
Islamic religious education and Manners is one of the principal subjects in every level of education in Indonesia. Through these subjects, expected learners have appropriate moral with the teachings of the Islamic religion (Isamic Values Morality). In fact, the Islamic religious education and learning Manners hasn't been fullest fruition, as evidenced by the diverse social irregularities committed by learners good level of elementary or high school. Therefore it is important to let the learning approach using a model Living Values Education (LVE). Because it is a personal approach with LVE mengidupkan twelve values (peace, respect, love, responsibility, joy, cooperation, honesty, humility, tolerance, simplicity and unity) that can assist in safely Isamic Values Morality. LVE then approaches through learning can be felt with the heart as well as implemented in everyday life by not forgetting that the educator is a great model for learners. The existence of the consistency between words and deeds of educators is crucial. The application of the approach to learning PAI and LVE in manners can be performed on the stage of the opening, the core and close by bringing positive energy like smiling and always appreciate as well as providing convenience for learners. so educators will get his heart and make it easy for yourself to develop the Isamic Values Morality as well as applied in everyday life.
\end{abstract}

Keywords: Living Values Education (LVE), Islamic Education Learning and Manners, Islamic Values Morality.

\section{Pendahuluan}

Pendidikan Agama Islam dan Budi Pekerti merupakan salah satu mata pelajaran wajib dalam setiap jenjang pendidikan di Indonesia. Adanya mata pelajaran tersebut ditujukan guna membentuk karakteristik peserta didik yang beradab sebagaimana cita-cita pendidikan di Indonesia yang tertuang dalam UU No. 20 tahun 2003 tentang Sistem Pendidikan Nasional, yakni membentuk peserta didik yang tidak hanya cerdas secara intelektual, namun juga cerdas secara moral (UU No. 20 Th 2003 Tentang Sistem Pendidikan Nasional). 


\section{Rofi'ah Nurhayati}

Tercapainya tujuan pendidikan sebagaimana yang dicita-citakan bangsa tentu tidak terlepas dengan peran pendidik sebagai salah satu komponen penting pendidikan sekaligus model bagi peserta didik. Tanpa adanya pendidik, maka materi pelajaran yang telah disusun rapi tidak akan sampai kepada peserta didik, maka pemerintah pun memberikan syarat-syarat kompetensi yang harus dimiliki oleh seorang pendidik profesional guna memiliki visi dan misi yang sama dengan pemerintah guna memberikan pembelajaran yang profesional dan menarik serta efisien dan efektif.

Faktanya, beragam kegiatan pembelajaran yang telah didesain oleh pendidik PAI dan Budi Pekerti di tingkat pendidikan belum membuahkan hasil gemilang. Terbukti dengan maraknya deviasi-deviasi nilai-nilai moral Islam (Islamic Values Morality) pada peserta didik, seperti membolos sekolah, tawuran antar pelajar yang menyebabkan kematian sebagaimana yang terjadi di Bekasi pada 16 September 2018 lalu (Haryudi, Pelajar Bogor Tewas Tawuran, Pelaku di Bawah Umur Tetap Diproses Hukum, diakses melalui https://metro.sindonews. com/read/1338632/170/pelajar-bogor-tewas-tawuran-pelaku-di-bawah-umur-tetap-diproseshukum-1537085135 pada tanggal 13 Oktober 2018) tawuran antar suku yang baru saja terjadi di daerah Seturan antara papua dan ambon pada 12 September, ricuh antar supporter yang menyebabkan kematian (Solopos.com, Detik-Detik Mencekam Tawuran Kelompok Papua dan Ambon di Depok Sleman

diakses melalui https://www.liputan6.com/regional/read/3642966/detik-detik-mencekamtawuran-kelompok-papua-dan-ambon-di-depok-sleman pada tanggal 13 Oktober 2018). Dan tidak berhenti sampai disini, minum-minuman keras yang mulai dari anak SD hingga para ABG pun marak dilakukan (Muhamad Rido, Pesta Miras ABG di gedung SD bikin resah, diakses melalui https://www.liputan6.com/regional/read/3652905/pesta-miras-abgdi-gedung-sd-bikin-resah pada tanggal 13 Oktober 2018). Selain itu, tidak asing lagi dalam pandangan kita banyak anak yang tidak patuh terhadap guru, melawan orang tua dan beragam tindakan lainnya yang kesemuanya bertentangan dengan nilai-nilai moral Islam.

Penyimpangan-penyimpangan di atas tidak dapat mutlak disalahkan kepada peserta didik. bukan hal mustahil, jika pembelajaran yang diberikan oleh pendidik di dalam kelas atau di sekolah tidak sampai ke hati, atau jusru hanya menjadi hafalan semata. Beragam pembelajaran dalam rumpun PAI dan budi bukan materi hafalan semata, sehingga menciptakan generasi wacana tanpa praktik. Namun, pembelajaran tersebut harus memberikan impresi yang kuat bagi peserta didik, baik karena pembelajara yang monoton atau hanya hafalan-hafalan yang disyaratkan. Untuk itu penting melakukan pembelajaran berbasis nilai yang menarik dan 
melibatkan peserta didik sehingga hasilnya sampai dihati bukan sebatas otak belaka lalu terbuang sia-sia. Atau dengan kata pendidik harus mampu memberikan pembelajaran yang bernilai sehingga peserta didik menjadi sadar akan nilai-nilai ke-Islaman. Yang kemudian nilai-nilai tersebut dapat diimplementasikan dalam kehidupan sehari-hari.

Living Values Education (LVE) merupakan salah satu pendekatan pembelajaran yang menyajikan beragam aktivitas pengalaman dan metodologi praktis yang dapat digunakan oleh pendidik dalam pembelajaran guna memberikan impresi positif karena pendekatan ini mengandung nilai-nilai kehidupan sebagaimana moral Islam seperti kejujuan, damai, toleransi, sederhana, tanggung jawab, dan lain sebagainya yang terbingkai dalam pembelajaran menarik dan tidak membosankan (Diane Tillman, 2004: ix). Selain itu, LVE juga mengakui bahwa semua peserta didik memiliki nilai-nilai yang layak dikembangkan dan diapresiasi. Tidak ada kata bodoh, ataupun terbelakang, karena LVE mengajarkan nilai-nilai yang saling menghargai dan mengarpresiasi setiap perkembangan dan perbedaan pada individu.

Nilai-nilai yang terdapat dalam LVE merupakan nilai universal yang dapat dikembangkan dalam keadaan apapun, baik konflik maupun damai. Tools yang terdapat di dalamnya pun lengkap, terlebih LVEP merupakan salah satu program di bawah PBB (Perserikatan BangsaBangsa) melalui lembaga UNESCO (Diane Tillman, 2004: ix) dan telah diterapkan dibanyak negara dengan tujuan untuk menghidupkan nilai-nilai kehidupan, dimana nilai-nilai tersebut tidka bertentangan dengan Islamic Values Morality.

Pendekatan yang dipilih oleh pendidik dalam pembelajrab merupkan hal yang penting, guna memberikan arah dan pedoman dalam pembeljaran. Jika pendidik tidak menggunakan pendketan yang tepat, tidak mjustahil jika beragam penyimpanbgan sosial kerap kali dilakukan. Hal ini dikarenakan, pembelajran PAI dna Budi pekerti hanya sebatas materi tanpa aplikasi. Tidak sampai menyentuh hati dan hanya pada tataran otak pun atau bahkan terbuang sia-sia. Melalui pendekatan yang menarik dan menyentuh hati maka kebosanan dalam pemelajaran akan terkikis menjadi kelas yang hidup dan menyenangkan. Maka, penerapan LVE dalam pembelajaran PAI dan Budi Pekrti merupakan hal yang penting untuk diterapkan guna membentuk Islamic Value Morality peserta didik.

Berdasarkan latar belakang di atas, penulis tertarik untuk mengkaji lebih lanjut terkait "Pendekatan Living Values Education dalam Pembelajaran PAI dan Budi Pekerti Sebagai Upaya Membentuk Islamic Value Morality Peserta Didik" dengan tujuan untuk dapat dijadikan sebagai refrensi bagi seluruh pendidik PAI dan Budi pekerti dalam mencapai tujaun 


\section{Rofi'ah Nurhayati}

pendidikan dengan metode penulisan yaitu studi literatur.

\section{Living Values Education (LVE)}

Living Values Education (LVE) pertama kali diperkenalkan di Indonesia pada tahun 2002. Program ini berbasis pada pendekatan nilai dimana pendidik tidak hanya bertugas untuk transfer of knowldege saja namun juga transformasi peserta didik melalui modelling, mengingat peserta didik dalam tahap pencarian jati diri dan lebih yakni lebih mengingat apa yang dilihat darai pada apa yang didengar (Desmita, 2003: 39).

LVEP merupakan program di bawah UNESCO yang digunakan untuk meningkatkan kompetensi pendidik khususnya kompetensi kepribadian, dengan memberikan kesadaran kepada pendidik untuk mampu merasakan dan melaksanakan apa yang telah diucapkan. Nilainilai yang dikembangkan dalam LVE berjumlah dua belas yakni kedamaian, penghargaan, cinta, tanggung jawab, kebahagiaan, kerjasama, kejujuran, kerendahan hati, toleransi, kesederhanaan dan persatuan.

LVE juga memiliki trainer-trainer bersertifikat internasional yang juga tersebar di Indonesia dan bekerjasama dengnan beberapa organsiasi seperti Karuna Foundation di Bali dengan trainernya Bpak Wayan Irianto, Rumah Kearifan di Yogyakarta dengan trainernya Bapak Muqowim, dan lain sebagainya. Umumnya untuk memperoleh sertifikat LVE peserta harus mengikuti pelatihan secara fullday selama dua hari.

Namun, berdasarkan pengalaman penulis, pelatihanLVEtidakmembosankansebagaimana pelatihan pada umumnya, karena di dalamnya akan dilatih self management, introspeksi diri, dan berpikir kedepan serta langkah konkrit yang akan dilakukan. Selain itu, LVEP juga akan memantau perkembangan program-program pada setiap lembaga yang mengikuti pelatihan.

LVE merupakan pendekatan pembelajaran dengan pendekatan personal, sehingga kebermanfaatan suatu ilmu dapat lebih terasa dan terpantau dengan baik, pendidik menjadi lebih peka dengan perkembangan peserta didik, dan pesreta didik akan semakin merasa dihargai dengan adanya rasa respect each others yang akan membentuk hubungan kekeluargaan antara pendidik dengan peserta didik yang lekat. Ketika pendidik telah mampu mendapatakan hati peserta didik maka akan dengan mudah menyampaikan beragam ilmu pengetahuan dan melakukan pendekatan nilai yang baik. Dalam hal ini, sudah barang tentu pendidik harus memiliki sikap konsistensi yakni melakukan apa yang diucapkan bukan sekedar omong kosong belaka. 
Tujuan-tujuan dari LVE yakni:

1. Untuk membangun individu memikirkan dan merefleksikan nilai-nilai yang berbeda dan implikasi praktis bila mengekspresikan nilai-nilai tersebut dalam hubungannya dengan diri sendiri, orang lain, masyarakat, dan seluruh dunia.

2. Untuk memperdalam pemahaman, motivasi dan tanggung jawab saat menentukan pilihan-pilihan pribadi dan sosial yang positif.

3. Untuk menginspirasi individu memilih nilai-nilai pribadi, sosial, moral dan spiritual, dan menyadari metode-metode praktis dalam mengembangkan dan memperdalam nilai-nilai tersebut.

4. Untuk mendorong para pengajar dan pengasuh memandang pendidikan sebagai sarana memberikan filsafat-filsafat hidup kepada murid, dengan demikian memfasilitasi pertumbuhan, perkembangan, dan pilihan-pilihan mereka sehingga mereka bisa berintegrasi dengan masyarakat dengan rasa hormat, percaya diri dan tujuan yang jelas (Diane Tillman, 2004: x)

Berdasarkan tujuan-tujuan di atas, dapat diketahui bahwa LVE sangat mendukung dalam orientasi pengembangan kinerja pendidik termasuk pendidik PAI dan Budi Pekerti, hal ini dikarenakan orientasi LVE tidka hanya memfokuskan pada diri sendiri namun juga orang lain. Perilaku pendidik yang baik tentu akan memebrikan teladan kepada peserta didik yang kemudian termanifestasi dalam kehidupan sehari-hari baik di sekolah maupun lingkungan masyarakat.

Selain tujuan tersebut, tiap nilai yang dikembangkan di dalam LVE memiliki butir-butir refleksi sebagai acuan dalam merasakan tiap nilai tersbut apakah telah terasa di dalam hati atau belum. Butir refleksi juga dapat digunakan sebagai alat untuk mengukur diri s a m pa i tahap mana pribadi seseorang mencapai taraf nilai tersebut. Hal ini dikarenakan butir-butir refleksi pada setiap nilai mengandung makna yang mendalam.

Misalnya pada butir refleksi kedamaian, Diane Tillman dalam buku LVEP menyebutkan:

1. Kedamaian berari tidak sekedar tidak adanya perang

2. Kedamaian dunia tumbuh dari non kekerasan, penerimaan, keadilan dan komunikasi 


\section{Rofi'ah Nurhayati}

3. Kedamaian dimuali dari setiap diri kita

4. Bukti dari suatu tindakan tergantung bukti dari orangnya

5. Kedamaian mengandung ikiran yang murni, perasan yang murni, dan harapan yang murni.

6. Agar tetap damai diperlukan asih dan kekuatan

7. "Kedaamaian harus diawali oleh kita masing-masing, melalui refleksi yang tenang dan serius, cara-cara baru dan kreatif dapat ditemukan untuk membangun pengertian, persahabatan, dan kerja sama diantara dua orang." -Javier Perez de Cueller, mantan Sekjen PBB (Diane Tillman, 2004: 4).

Butir-butir refleksi di atas adalah salah satu dari butir-butir refleksi nilai-nilai dalam LVE yakni kedamaian. Didalam butir-butir tersebut jelas mengandung makna damai dan bagaimana menciptakan kedamaian yang dimulai dari diri sendiri. Ketika kita berdamai, maka orang lain pun akan damai dengan kita. Dengan ini maka menambah kekuatan bahwa nilai-nilai dalam LVE dapat memberikan perubahan sikap dan tingkah laku dalam dunia pendidikan khususunya peserta didik dan pendidik guna mencapai tujuan pendidikan yakni menciptakan peserta didik yang bermoral, yang dalam hal ini dibasiskan dalam ajaran agama Islam.

\section{Islamic Values Morality (Nilai Moral Islam)}

Secara etimologis, kata moral berasal dari kata mos dalam bahasa Latin, bentuk jamaknya mores yang berarti tata cara atau adat istiadat yang berlaku pada suatu tempat tertentu. Moralitas juga dapat diartikan sebagai sifat atau keselurhan asas dan nilai yang terkandung berkenaan dengan yang baik atau buruk (K. Bertens, 2011: 7). Dalam Kamus Besar Bahasa Indonesia, moral diartikan sebagai ajaran tentang baik buruk yang diterima umum mengenai perbuatan, sikap, kewajiban, dan sebagainya (KBBI, 2005: 225). Dengan demikian dapat disimpulkan bahwa moral merupakan perangai yang dapat dinilai sebagai perangai atau akhlak yang baik ataupun buruk berdasarkan nilai-nilai norma yang telah ada.

Islamic Values Morality atau yang disebut dnegan moral Islam merupakan perilaku yang termanifestasi dalam kehidupan sehari-hari berlandaskan nilai-nilai Islam. Nilai-nilai 
Islam atau yang disebut dengan akhlak Islamiyah terdapat dalam Alquran dan hadits serta beragam kisah yang dapat diambil ibrahnya.

Seseorang yang menerapkan nilai moral Islam, tentu mempelajarai Islam tidak hanya pada taraf hafalan namun dalam taraf kesadaran. Sehingga nilai tersebut dapat dirasakan dengan khidmat dan diimplementasikan dalam kehidupan sehari-hari. Dalam pembelajaran PAI dan Budi Pekerti, Islamic Values Morality terdapat dalam setiap bab pembelajarannya dari tingkat SD bahkan sampai SMA membahas nilai yang tidak jauh berbeda. Namun, faktanya tidak sedikit guru PAI dan Budi Pekerti yang hanya transfer of knowledge sehingga Islamic Value tidak menjadi moral yang teraplikasikan melainkan sebagai wacana dan hafalan semata. Penilaian yang diunggulkan hanya berdasar kognitif belaka sedangkan penilaian psikomotor dan afektif hanya formalitas belaka. Apalagi, jika sekolah tidak mau memberikan nilai apa adanya dan idealis untuk memberikan nilai terbaik kepada setiap peserta didiknya meskipun sejatinya ia tidaka layak untuk mendapatkan nilai tersebut.

Dalam hal ini tentu, guru dan kepala sekolah serta setiap karyawan harus mampu menjadi model bagi setiap peserta didik. apalagi mereka masih dalam tahap meniru apa yang dilihat. Impresi kuat dalam tatapan dibanding dari apa yang didengar menjadi cambuk bahwa kepribadian guru merupakan hal yang vital untuk Membentuk Islamic Values Morality. Guru merupakan komponen penddikan penting yang tidak boleh diabaikan oleh pemerintah terkait kualitasmya, terlebih guru merupakan pelaksana pendidikan yang langsung bersentuhan dengan setiap peserta didiknya. Siap untuk membentuk mindset positif atau bahkan radikalism. Untuk itulah adanya pengelolaan moral guru atau kepribadian pendidik merupakan hal yang vital untuk membentuk Islamic Value Morality pada peserta didik.

\section{Penerapan Pendekatan LVE Pada Pembelajaran PAI dan Budi Pekerti}

Pendekatan LVE dalam pembelajaran PAI dan budi pekerti bukan sebatas wacana, namun dapat diaplikasikan dalam pembelajaran secara langsung baik di dalam kelas maupun diluar kelas. Meskipun, tujuan pendidikan tidak dapat tercapai hanya pada saau lembaga atau satu unsur tripusat pendidikan (Said Suhil Achmad, Pengantar Pendidikan Kegiatan 4, diakses melalui http://saidsuhilachmad.yolasite.com/resources /kegiatan_4\%20PP.Pdf pada tanggal 1 November 2018). Namun, lembaga pendidikan merupakan salah satu hal vital yang harus dibenahi. Terlebih pada pembelajran agama Islam yang mengajarkan beragam akhlak untuk diterapkan dalam kehidupan sehari-hari. 


\section{Rofi'ah Nurhayati}

Nilai-nilai di dalam LVE tidak harus diterapkan semuanya dalam waktu serentak, namun dapat dianalisa terlebih dahulu disesuaikan dengan kebutuhan sekolah (Muqowim, Wawancara Pribadi: 31 Oktober 2018). Hal ini ditujukan untuk meningkatkan efektivitas dan efisiensi waktu guna mendapatkan hasil yang maksimal.

Penerapan LVE dalam pembelajaran PAI dan Budi Pekerti dapat membuat pesreta didik menjadi nyaman, lebih dihargai, karena LVE meyakini bahwa setiap peserta didik memiliki keunikan masing-masing yang layak diapresiasi (Diane Tillman, 2004: 4), tidak ada labelling anak nakal, anak bodoh dan lain sebagainya. Semuanya dianggap pesreta didik dan berhak menerima pembelajaran dengan baik melalui pendekatan pembelajaran yang berkualitas.

LVE melakukan pendekatan secara personal dan komunitas di dalam kelas dimana guru dilatih untuk mampu mengamati perubahan satu persatu pada setiap peserta didik, sehingga ketika didapati adanya perbedaan atau hal yang aneh pada perkembangan peserta didik akan segera untuk ditindaklanjuti. LVE merupakan pendekatan menghidupkan nilai dengan pendidik langsung menjadi model bagi seluruh peserta didiknya.

Penerapan LVE dalam pembelajaran dapat dilaksnakan pada setiap tahap-tahap pembelajaran, dimulai pembukaan, inti dan penutup. Pada pembukaan guru memberikan senyum dan membawa energi positif bagi seluruh warga kelas, senyum merupakan salah satu cara menebar kedamaian, kebahagiaan, serta melatih diri untuk berpikir positif. Selain itu, senyum juga dapat memberikan energi positif bagi lawan bicaranya. Kemudian menanyakan kepada pserta didik melalui kehadiran dan melatih untuk jujur ketika terdpat epserta didik yang ditanyai, dalam hal ini pendidik tentu harus memahami kepribaidna peserta didik sehingga cara-cara pembelajaran juga disesuaikan dengan tahap perkembangan psikologinya.

Pada tahap inti, pendidik dapat melakukan pembelajaran dengan beragam permainan, sehingga antar satu peserta didik dengan peserta didik yang lainnya menjadi lebih mengenal dan menumbuhkan rasa respect each other. Sedangkan pada tahap penutup ketika pendidik dapat menggunakan beragam cara baik permainan yang menarik ataupun melalui lembar kertas. Dalam LVE setiap peserta didik harus melakukan perubahan pada kehidupan sehari-hari dan minimal melakukan satu kebaikan dimulai dari saling maaf dan memaafkan, menerapkan kebaikan dengan tersenyum atau sekedar beruluk salam. Hal ini merupakan cara sederhana tapi mengena di hati dan sering diabaikan. 
Selain itu, strategi lain yang dapat diterapkan melalui pendekatan LVE adalah dengan melakukan beragam permainan sebagaimana terdapat dalam tools LVE dalam guidence book yang telah dibuat oleh LVE International. Melalui guidence book akan diketahui secara rinci tentang tahap-tahap yang harus dilakukan. Namun, bukan hal mustahil jika penerapan LVE juga dapat dikmbinasi dari strategi pembelajaran lain. Dengan LVE sebagai ruh untuk membentuk Islamic Values Morality sedangkan strategi permainan digunakan untuk mengahangatkan saja. Salah satu buku yang dapat digunakan adalah buku "101 Strategi pembelajaran" karangan Melvin L Silberman.

Tidak sedikit pendidik yang hanya berorientasi pada hasil koginitifdan tidak memperhatikan pada aspek sikap peserta didik. Jangankan memperhatikan sikap peserta diidk, untuk respect dan tersenyum pun mahal harganya. Hal ini membuat pesreta didik tidak nyaman, hanya tegang, diam, namun gemetar, akibatnya apapun yang disampaikan pendidik tidak akan membuahkan hasil.

Namun, jika pendidik mampu mengambil hati peserta didik, dengan menciptakan pembeklajaran PAI dan Budi Pekerti yang nyaman dan menyenangkan maka, melatih nilai nilai kehidupan bukanlah suatu hal yang sulit, disamping pendidik juga harus mampu menjadi model. Terlebih nilai-nilai dalam Islam tidak bertentangan dengan nilai-nilai LVE seperti damai, sebagaiman terdapat dalam Q.S. Alhujurat ayat 13 bahwa adanya perbedaan adalah suatu rahmat, dengan memahami perbedaan maka akan menimbulkan rasa respect each other. Selain itu juga nilai toleransi (Q.S. Al kfirun), sabar, bertanggung jawab, bahagia, dna lain segaianya. Ke duaa belas nilai yang terkandung dalam LVE tidak membelakangi ataupun bertolak belakang dengan nilai Islam, namun justru menguatkan dan membantu membumikan Islamic Value Morality. Dengan demikian, maka penerapan pendekatan LVE dalam pembelajaran PAI dan budi Pekerti dapat membentuk Islamic Value Morality pada peserta didik.

\section{Kesimpulan}

Pendekatan LVE dalam pembelajaran PAI dan Budi Pekerti dapat membentuk peserta didik yang sadar dnegan Islamic Value Morality, terlebih pendidik juga sadar dengan tugas dan fungsinya yang tidak hanya sebatas transfer of knowledge, namun nuga transformasi peserta didik. Nilai-nilai dalam LVE yakni, kedamaian, pengahrgaan, cinta, tanggung jawab, kebahagiaan, kerja sama, kejujuran kerendahan hati, toleransi, kesederhanaan dan persatuan. Kesemua nilai tersebut jika diterapkan baik secara serentak maupun satu persatu 


\section{el-Tarbawi \\ Rofi'ah Nurhayati}

akan mewujudkan Islamic Value Morality secara fakta bukan wacana belaka. Penerapa pendekatan LVE ini dapat dilakukan pada semua tahap pembelajaran (pendahuluan, inti dan penutup) seperti tersenyum ketika masuk kelas, memberikan motivasi positif dan beragam hal lain yang membangun. LVE bukan pendekatan yang menjatuhkan namun justru membangkitkann dan tidak menyombongkan. Oleh karen aitu, penerapan LVE dalam pembelajaran PAI dan Budi Pekerti merupakan salah satu cara untuk membentuk Islamic Value Morality pada setiap peserta didik. kendati demikian, guna mencapai tujuan pendidikan yang dicita-citakan tentu lembaga poendidikan tidak dapat bekerja sendiri, melainkan membutuhkan kerjasama harmonis antar komponen pendidikan dan tripusat pendidikan, karena keberhasilan pendidikan merupakan tanggumg jawab bersama. 


\section{Daftar Pustaka}

Anwar,Firdaus.(2018).AdayangMeninggalLagi, MengapaKekerasanBegituMelekatPada Suporter?, diakses melalui https://health.detik.com/berita-detikhealth/d-4225785/ ada-yang-meninggal-lagi-mengapa-kekerasan-begitu-melekat-pada-suporter? $\mathrm{ga}=2.19346812 .599611174 .1539393316-944224416.1539393316$ pada tanggal 13 Oktober 2018.

Departemen Pendidikan Nasional. (2005). Kamus Besar Bahasa Indonesia. Jakarta: Balai Pustaka.

Desmita. (2003). Psikologi Perkembangan Peserta Didik: Panduan bagi orangtua dan guru dalam Memahami Psikologi Anak Usia SD, SMP, dan SMA. Bandung: PT Remaja Rosdakarya.

Haryudi. (2018). Pelajar Bogor Tewas Tawuran, Pelaku di Bawah Umur Tetap Diproses Hukum, diakses melalui https://metro.sindonews.com/read/1338632/170/pelajarbogor-tewas-tawuran-pelaku-di-bawah-umur-tetap-diproses-hukum-1537085135 pada tanggal 13 oktober 2018

K. Bertens. (2011). Etika. Jakarta: Gramedia.

Rido, Muhamad. (2018). Pesta Miras ABG di gedung SD bikin resah, diakses melalui https://www.liputan6.com/regional/read/3652905/pesta-miras-abg-di-gedung-sdbikin-resah pada tanggal 13 Oktober 2018

Solopos.com. (2018). Detik-Detik Mencekam Tawuran Kelompok Papua dan Ambon di Depok Sleman diakses melalui https://www.liputan6.com/regional/read/3642966/ detik-detik-mencekam-tawuran-kelompok-papua-dan-ambon-di-depok-sleman pada tanggal 13 Oktober 2018. 


\section{di Trabbue \\ Jurnal penodotran islam Rofi'ah Nurhayati}

Suhil Achmad, Said. Pengantar Pendidikan Kegiatan 4, diakses melalui http:// saidsuhilachmad.yolasite.com/resources /kegiatan_4\%20PP.Pdf pada tanggal 1 Novemberf 2018).

Tillman, Diane. (2004). Living Values Activities for Young Adults, terj. Risa Praptono. Jakarta: Grasindo

UU No 20 Tahun 2003 tentang Sistem Pendidikan Nasional 